\title{
REFERENCES
}

\section{Evolving Style in the Super Mario Bros. 3 Soundtrack (Head)}

1 Super Mario Bros. 3. Kyoto: Nintendo, 1988.

2 Super Mario Bros. Kyoto: Nintendo, 1985.

3 "Iwata Asks | 4. Music Commentary by Koji Kondo (1)." Nintendo. Interview. Accessed 16 April 2013. http://www.nintendo.co.uk/Iwata-Asks/Iwata-AsksSuper-Mario-All-Stars/Vol-1-Super-Mario-History-Soundtrack-CD/1-Ma rio-s-Most-Representative-Music/1-Mario-s-Most-Representative-Music -219798.html.

4 Matthew Belinkie, "Video game music: not just kid stuff." 15 December 1999. Accessed 15 March 2013. http://www.vgmusic.com/vgpaper.shtml.

5 Ibid.

6 Whalen, Zach. "Play Along - An Approach to Videogame Music." Game Studies Volume 4, Issue 1 (2004). http://www.gamestudies.org/0401/whalen/.

7 Collins, Karen. Game Sound: An introduction to the History, Theory, and Practice of Video Game Music and Sound Design. Cambridge, MA: MIT Press, 2008, 25.

8 Brame, Jason. "Thematic Unity Across a Video Game Series." ACT - Zeitschrift für Music \& Performance 2 (2011), 12.

9 "Iwata Asks."

10 Collins, Karen. 17-8.

11 "Iwata Asks."

12 Philip Kim, Super Mario Brothers 3: Transcriptions/Arrangements for the Piano. Web. March 2007. Accessed 14 April 2013. http://mousouhousyutu.moo.jp/ smb3.pdf.

Additional References: (denoted with parenthetical citation):

Belinkie, Matthew. "Video game music: not just kid stuff." 15 December 1999. Accessed 15 March 2013. http://www.vgmusic.com/vgpaper.shtml.

Brame, Jason. "Thematic Unity Across a Video Game Series.” ACT - Zeitschrift für Music \& Performance 2 (2011).

Chris. "Koji Kondo :: Biography.” SquareEnixMusic.com. Web. 17 November 2008. Accessed 15 March 2013. http://www.squareenixmusic.com/composers/ kondo/biography.shtml.

Collins, Karen. "From Bits to Hits: Video Game Music Changes its Tune." Film International 12 (2005), 4-19.

Collins, Karen. Game Sound: An introduction to the History, Theory, and Practice of Video Game Music and Sound Design. Cambridge, MA: MIT Press, 2008.

Collins, Karen. "In the Loop: Creativity and Constraint in 8-bit Video Game Audio." Twentieth-Century Music 4/2 (2008), 209-227.

Fritsch, Melanie. "History of Video Game Music," in Music and Game: Perspectives on a Popular Alliance, edited By Peter Moormann, 11-40. Berlin: Springer VS, 2013. 
"Interview with Koji Kondo (Electronic Gaming Monthly - December 2005). SquareEnixMusic.com. Interview. Accessed 15 March 2013. http://www. squareenixmusic.com/composers/kondo/dec05interview.shtml.

"Iwata Asks | 1. Mario's Most Representative Music." Nintendo. Interview. Accessed 16 April 2013. http://www.nintendo.co.uk/Iwata-Asks/Iwata-Asks-SuperMario-All-Stars/Vol-1-Super-Mario-History-Soundtrack-CD/1-Mario-sMost-Representative-Music/1-Mario-s-Most-Representative-Music-219798. html.

"Iwata Asks | 4. Music Commentary by Koji Kondo (1)." Nintendo. Interview. Accessed 16 April 2013. http://www.nintendo.co.uk/Iwata-Asks/IwataAsks-Super-Mario-All-Stars/Vol-1-Super-Mario-History-SoundtrackCD/4-Music-Commentary-by-Koji-Kondo-1-/4-Music-Commentary-byKoji-Kondo-1--219986.html.

Kennedy, Sam, and Thomas Puha. "Super Mario Bros. Composer Koji Kondo Interview from 1UP.com.” 1UP.com. Interview. 19 October 2007. Accessed 16 April 2013. http://www.1up.com/features/mariomaestro.

Kim, Philip. Super Mario Brothers 3: Transcriptions/Arrangements for the Piano. Web. March 2007. Accessed 14 April 2013. http://mousouhousyutu.moo.jp/smb3. pdf.

Kikizo Staff. "Nintendo Interview: Koji Kondo" VideoGamesDAILY.com. Interview. 10 May 2007. Accessed 15 March 2013. http://archive.videogamesdaily.com/ features/koji_kondo_iv_p1.asp.seanmalstrom. "The Music of Super Mario Brothers 3." Malstrom's Articles News. Web. 24 November 2010. Accessed 14 April 2013. http://seanmalstrom.wordpress.com/2010/11/24/the-music-of-supermariobrothers-3/.

Whalen, Zach. "Play Along - An Approach to Videogame Music." Game Studies Volume 4, Issue 1 (2004). http://www.gamestudies.org/0401/whalen/ 


\section{REFERENCES (continued)}

\section{Cross Cultural Considerations for Craniofacial Anomalies (Zhang)}

1 Palkes, Helen S, Jeffrey L Marsh, and Barbara K Talent. "Pediatric craniofacial surgery and parental attitudes." Cleft Palate Journal 23, no. 2 (1986): 137 143. Quotation: p. 137.

2 Ibid.

3 Ibid.

4 Ibid.

5 Ibid.

6 Ibid.

7 Ibid.

8 Ibid.

9 Ibid.

10 Bemmels, Heather, Barbara Biesecker, Johanna Schmidt, Alyson Krokosky, Rick Guidotti, and Erica Sutton. "Psychological and Social Factors in Undergoing Reconstructive Surgery among Individuals with Craniofacial Conditions: An Exploratory Study." The Cleft Palate-Craniofacial Journal 50, no. 2 (2013): 158-167.

11 Ibid.

12 Ibid.

13 Strauss, Ronald P., Hillary Broder, and Ronald W. Helms. "Perceptions of appearance and speech by adolescent patients with cleft lip and palate and by their parents." Cleft Palate Journal 25, no. 4 (1988): 335-342.

14 Ibid.

15 Ibid.

16 Ibid.

17 Strauss, Ronald P., and Hillary Broder. "Directions and issues in psychosocial research and methods as applied to cleft lip and palate and craniofacial anomalies." The Cleft Palate-Craniofacial Journal 28, no. 2 (1991): 150-156. Quotation: p. 151.

18 Ibid.

19 Ibid.

20 Pannbacker, Mary, and Jane Scheuerle. "Parents' attitudes toward family involvement in cleft palate treatment." The Cleft Palate-Craniofacial Journal 30, no. 1 (1993): 87-89.

21 Ibid.

22 Foo, Peter, Wayne Sampson, Rachel Roberts, Lisa Jamieson, and David David. "General health-related quality of life and oral health impact among Australians with cleft compared with population norms; age and gender differences." The Cleft Palate-Craniofacial Journal 49, no. 4 (2013): 406413.

23 Ibid. 
24 Turner, S.R., N. Rumsey, and J.R. Sandy. "Psychological aspects of cleft lip and palate." European Journal of Orthodontics 20 (1998): 407-415.

25 Ibid.

26 Ibid.

27 Sharif, Mohammad Owaise, Peter Callery, and Stephanie Tierney. "The Perspectives of Children and Young People Living with Cleft Lip and Palate; a Review of Qualitative Literature.” The Cleft Palate-Craniofacial Journal 50, no. 3 (2013): 297-304.

28 Pope, Alice W, and Heather T Snyder. "Psychosocial adjustment in children and adolescents with a craniofacial anomaly: age and sex patterns." The Cleft Palate-Craniofacial Journal 42, no. 4 (2005): 349-354.

29 Strauss, Ronald P. "Culture, rehabilitation, and facial birth defects: international case studies.” Cleft Palate Journal 22, no. 1 (1985): 56-62.

30 Ibid.

31 Ibid, 57.

32 Ibid.

33 Ibid.

34 Ibid, 58.

35 Ibid.

36 Ibid.

37 Scheper-Hughes, Nancy. "Difference and danger: the cultural dynamics of childhood stigma, rejection, and rescue." Cleft Palate Journal 27, no. 3 (1990): 301-310.

38 Ibid, 302.

39 Ibid.

40 Ibid.

41 Ibid.

42 Ibid.

43 Ibid.

44 Ibid.

45 Ibid.

46 Nelson, Pauline A. "Qualitative approaches in craniofacial research." The Cleft Palate-Craniofacial Journal 46, no. 3 (2009): 245-249.

47 Loh, John, and Micol Ascoli. "Cross-cultural attitudes and perceptions towards cleft lip and palate deformities." World Cultural Psychiatry Research Review 6, no. 2 (2011): 127-134.

48 Ibid.

49 Ibid.

50 Ibid.

51 Ibid.

52 Ibid.

53 Naram, Aparajit, Sumeet Makhijani, Deepak Naram, Srinivas Gosia Reddy, Rajgopal R Reddy, Janice F Lalikos, and Jerome Donald Chao. "Perceptions of Family Members of Children with Cleft Lip and Palate in Hyderabad, India, and its rural outskirts regarding Craniofacial Anomalies: A Pilot Study." The Cleft Palate-Craniofacial Journal 50, no. 3 (2013): 41-46. 54 Ibid. 


\section{REFERENCES (continued)}

\section{Identity and the Narrative of Conflict (Perelshteyn)}

1 Tessler, Mark. "Jews and Arabs before the Conflict." A History of the Israeli-Palestinian Conflict. Indiana University Press: 1994. pp. 2.

2 Ibid, 3.

3 Motyl, Alexander J. (2001). Encyclopedia of Nationalism, Volume II. Academic Press. 4 Rotberg, Rober I. (Editor). Israeli and Palestinian Narratives of Conflict: History's Double Helix. Bloomington, IN, USA: Indiana University Press, 2006. pp. 59. 5 Ibid, 59.

6 Dawisha, Adeed. Requiem for Arab Nationalism, Middle East Quarterly, Winter 2003, pp. 25-41.

7 Amadouny, V.M. The Formation of the Transjordan-Syria Boundary, 1915-1932, Middle Eastern Studies, Vol. 31, No. 3. Taylor \& Francis, Ltd.: USA. pp. 535-536.

8 Yapp, M.E. (1987-09-01). The Making of the Modern Near East 1792-1923. Harlow, England: Longman. pp. 290.

9 Tessler pp. 185.

10 Ibid, 186-196.

11 Ibid, 211.

12 Ibid, 221.

13 Ibid, 215.

14 Ibid, 213.

15 Ibid, 256.

16 Ibid, 259.

17 Ibid, 259.

18 Ibid, 259.

19 Ibid, 264.

20 Ibid, 264.

21 Ibid, 387.

22 Ibid, 394.

23 Ibid, 405.

24 Ibid, 475.

25 Ibid, 475.

26 Ibid, 489.

27 Ibid, 495.

28 Mattar, Philip (2005). Encyclopedia of the Palestinians. Facts on File, Inc: USA. pp. 62.

29 http://news.bbc.co.uk/2/hi/in_depth/middle_east/israel_and_the_palestinians/key documents/1682727.stm.

30 Malley, Robert (2001). "Camp David: Tragedy of Errors.” Journal of Palestine Studies XXXI, no. 1. pp. 62-85.

31 Ibid. 
32 Frisch, Hillel (2009). “The Need for a Decisive Israeli Victory Over Hamas.” BESA Center Perspectives Papers No. 57, January 2009.

33 Ibid.

34 Rotberg, Robert I. (Editor). Israeli and Palestinian Narratives of Conflict: History's Double Helix. Bloomington, IN, USA: Indiana University Press, 2006. pp. 23.

35 Ibid, 23.

36 Ibid, 24.

37 Ibid, 74.

38 Ibid, 82.

39 Ibid, 83.

40 Ibid, 56.

41 Ibid, 56.

42 Ibid, 72.

43 Ibid, 73.

44 Ibid, 84.

45 Ibid, 75.

46 Ibid, 76.

47 Ibid, 77.

48 Ibid, 77.

49 Ibid, 80.

50 Ibid, 80.

51 "The Parents Circle Families Forum - Introduction." The Parents Circle Families Forum - Introduction. N.p., n.d. Web. 29 Apr. 2013. http://www.theparentscircle .com/Content.aspx?ID=2\#.UX7d7ZUtxUQ.

52 “Interfaith Encounter.” Interfaith Encounter. N.p., n.d. Web. 29 Apr. 2013. http:// interfaithencounter.wordpress.com/groupseventsprojects/projects/.

53 “About Youth Development.” About Youth Development. N.p., n.d. Web. 29 Apr. 2013. http://www.newprofile.org/english/youth_en. 


\section{REFERENCES (continued)}

\section{"Live and Let Live": The Destabilization of Heteronormativity in Moisés Kaufmann's "The Laramie Project" (Bollas)}

1 Sedgwick, Kosofsky Eve. "Introduction." Between Men English Literature and Male Homosocial Desire. New York: Columbia UP, 1985. 1-20. Print. Referenced: p. 2-5.

2 Kaufmann, Moisés. The Laramie Project / by Moisés Kaufman and the Members of Tectonic Theater Project. New York: Vintage, 2001. Print. Quotation: p. 78-79.

3 Ibid, 58.

4 Ibid, 25.

5 Ibid, 27.

6 Ibid, 69.

7 Ibid, 12.

8 Ibid, 13.

9 Ibid, 58.

10 Ibid, 48.

11 Ibid, 49.

12 Ibid, 71.

13 Ibid, 45.

14 Ibid, 19.

15 Ibid, 31.

16 Loffreda, Beth. "Chapter Three.” Losing Matt Shepard: Life and Politics in the Aftermath of Anti-gay Murder. New York, NY: Columbia Univ., 2000. 63-89. Print. Referenced: p. 63.

17 Ibid, 71.

18 Ibid, 67.

19 Ibid, 80.

20 Kaufmann, Moisés. The Laramie Project / by Moisés Kaufman and the Members of Tectonic Theater Project. New York: Vintage, 2001. Print. Quotation: p. 78-79. Quotation: p. 59.

21 Ibid, 20.

22 Ibid, 66.

23 Kantor, Martin. "Homophobia in Gays and Lesbians." Homophobia: Description, Development, and Dynamics of Gay Bashing. Westport, CT: Praeger, 1998. 51 62. Print.

24 Atkinson, Elizabeth and Renee DePalma. "Un-believing the Matrix: Queering Consensual Heteronormativity.” Gender and Education 21.1 (2009): 17-29. Academic Search Premier. Web. 1 Apr. 2011.

25 Kaufmann, Moisés. "Into the West: An Exploration in Form." American Theatre 17.5 (2000): 17-18. MLA International Bibliography. Web. 27 Mar. 2011. 
26 Brown, Rich. "Moises Kaufmann: The Copulation of Form and Content." Theatre Topics 15.1 (2005): 51-67. Project MUSE. Web. 27 Jan. 2011.

27 Baglia, Jay, and Elissa Foster. "Performing the "Really" Real: Cultural Criticism, Representation, and Commodification in The Laramie Project." EBSCO Open Access Journal 19.2 (Spring 2005): 127-45. Print.

28 Kaufmann, Moisés. The Laramie Project / by Moisés Kaufman and the Members of Tectonic Theater Project. New York: Vintage, 2001. Print. Quotation: p. 25.

29 Ibid, 71.

30 Ibid, 64.

31 Lippert, Leopold. "'Life in the Memory of One Who No Longer Lives': The Laramie Project and the Politics of Performance.” ANQ: A Quarterly Journal of Short Articles, Notes, and Reviews 23.2 (2010): 86-95. Academic Search Premier. Web. 21 Jan. 2011.

32 Kaufmann, Moisés. The Laramie Project / by Moisés Kaufman and the Members of Tectonic Theater Project. New York: Vintage, 2001. Print. Quotation: p. 98. 